\title{
MEMBANGUN PERILAKU SADAR EKOLOGIS DAN EKONOMIS IBU RUMAH TANGGA MELALUI REORIENTASI PEMANFAATAN SAMPAH PERUMAHAN DI BTN BANYUNING INDAH
}

\author{
I Gede Astra Wesnawa ${ }^{1)}$, Putu Indra Christiawan ${ }^{1{ }^{*}}$ dan I Nengah Suarmanayasa ${ }^{1)}$ \\ 1) Universitas Pendidikan Ganesha, Singaraja \\ ${ }^{*}$ Email : indra.christiawan@undiksha.ac.id
}

\begin{abstract}
ABSTRAK
Secara keruangan, sampah rumah tangga adalah sampah paling besar yang dihasilkan di wilayah perkotaan, terutama pada bagian wilayah perkotaan yang digunakan sebagai kawasan perumahan. Pemukim BTN Banyuning Indah mayoritas adalah pendatang dengan mata pencaharian yang sangat heterogen. Kondisi ini mengakibatkan pemukim di BTN Banyuning Indah adalah produsen sampah terbesar di Kota Singaraja. Pemukim perumahan, khususnya ibu-ibu rumah tangga sebagai mitra adalah masyarakat yang belum produktif secara ekonomi. Permasalahan yang dihadapi mitra adalah: (1) permasalahan sampah yang mengarah pada penurunan kualitas lingkungan, (2) pemanfaatan potensi jumlah sampah yang belum optimal dan (3) pengelolaan sampah yang masih konvensional. Berdasarkan permasalahan yang dihadapi mitra tersebut, maka solusi yang ditawarkan dalam adalah membantu mitra dalam mengelola sampah secara kolektif-aktif dan berorientasi keuntungan ekologis dan ekonomis dengan: (1) membangun perilaku sadar ekologis dan ekonomis serta (2) mereorientasi pemanfaatan sampah. Program kemitraan ini dilaksanakan dengan pola pembinaan kepada mitra yang nantinya akan mengelola sampah perumahan.
\end{abstract}

Kata-Kata Kunci: Sadar Ekologis, Sadar Ekonomis dan Re-orientasi Pemanfaatan Sampah

In spatial terms, household waste is the largest waste produced in urban areas, especially in urban areas that are used as residential areas. The majority of BTN Banyuning Indah settlers are immigrants with very heterogeneous livelihoods. This condition resulted in settlers at BTN Banyuning Indah being the largest waste producer in Singaraja City. Resident settlers, especially housewives as partners are people who have not been economically productive. The problems faced by partners are (1) garbage problems that lead to a decrease in environmental quality, (2) utilization of the potential amount of waste that is not optimal and (3) conventional waste management. Based on the problems faced by these partners, the solution offered is to assist partners in managing waste collectively-actively and ecologically and economically profitoriented by (1) building ecologically and economically conscious behavior and (2) reorienting waste utilization. This partnership program is implemented with a pattern of guidance to partners who will later manage residential waste. 


\section{PENDAHULUAN}

Wilayah perkotaan adalah bagian dari ruang permukaan bumi yang secara masif sangat dipengaruhi oleh hubungan tersebut. Dinamika masyarakat perkotaan, baik dari segi pertumbuhan penduduk maupun dari segi aktivitas mereka akan memberi dampak terhadap kondisi dan kualitas lingkungan. Salah satu dampak negatif dari hubungan tersebut adalah permasalahan sampah, khususnya sampah yang bersifat perkotaan (urban waste). Sampah perkotaan yang dihadapi berbagai kota di dunia pada umumnya, dan kota-kota di Indonesia pada khususnya adalah sampah rumah tangga atau sampah domestik yang bersifat limbah padat atau dikenal dengan istilah municipal solid waste (MSW). Sampah perkotaan atau MSW adalah limbah rumah tangga perkotaan yang terdiri dari barang-barang sehari-hari seperti kemasan produk, potongan rumput, furnitur, pakaian, botol, sisa makanan, surat kabar, peralatan dan baterai (EPA, 2011). Sejalan dengan batasan tersebut, dalam PP No. 81 Tahun 2012 tentang Pengelolaan Sampah Rumah Tangga Dan Sampah Sejenis Sampah Rumah Tangga dijelaskan bahwa sampah rumah tangga adalah sampah yang berasal dari kegiatan sehari-hari dalam rumah tangga yang tidak termasuk tinja dan sampah spesifik. Sampah perumahan adalah jenis atau komposisi sampah yang paling cepat diproduksi dan memerlukan waktu yang sangat lama untuk terurai.

Kelurahan Banyuning merupakan bagian dari wilayah Kota Singaraja. Kota Singaraja adalah ibukota Kabupaten Buleleng, yang merupakan kabupaten dengan luas wilayah terbesar di Pulau Bali. Berdasarkan data BPS Kabupaten Buleleng tahun 2014 menunjukkan bahwa Kelurahan Banyuning merupakan kelurahan dengan luas wilayah terbesar, yaitu 5,13 $\mathrm{km}^{2}$ atau $18,39 \%$ dari total luas wilayah Kota Singaraja. Kelurahan Banyuning adalah wilayah yang potensial dan strategis dalam pengembangan kota. Pengembangan kota yang mendominasi penggunaan lahan di Kelurahan Banyuning adalah pengembangan permukiman, khususnya kompleks perumahan.

BTN Banyuning Indah adalah kompleks perumahan yang memiliki jumlah kepala keluarga (KK) terbesar di Kelurahan Banyuning. Kompleks perumahan BTN Banyuning memiliki jumlah KK sebesar 466 KK yang tersebar dalam 9 Blok rumah, yaitu dari Blok A hingga Blok I. Dari kesembilan blok rumah tersebut, Blok I adalah blok yang memiliki jumlah KK terbesar, yaitu 64 KK. Hal ini dikarenakan blok I adalah blok terbaru, yang baru dikembangkan developer pada tahun 1994

Pemukim BTN Banyuning Indah adalah penduduk pendatang dengan pekerjaan yang bersifat heterogen, terutama pada sektor industri dan jasa di Kota Singaraja. Dengan demikian, pemukim yang bermukim di BTN Banyuning Indah merupakan produsen sampah perkotaan terbesar di Kota Singaraja.

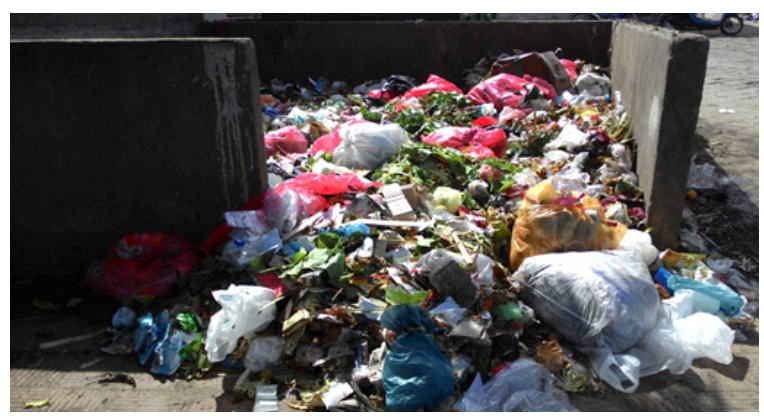

Gambar 1. Kondisi TPS di lingkungan BTN Banyuning Indah

Produksi sampah yang besar akan berimplikasi pada kebutuhan ruang bagi timbulan sampah yang besar. Secara teoritis timbulan sampah disebabkan oleh: (1) jumlah penduduk dan tingkat pertumbuhan penduduk, (2) tingkat hidup, yaitu makin tinggi tingkat hidup masyarakat, makin besar timbulan sampahnya, (3) musim, (4) cara hidup dan (5) mobilitas (Damanhuri \& Padmi, 2010). Secara praktis timbulan sampah di BTN Banyuning Indah disebabkan oleh kesenjangan antara peningkatan produksi sampah dengan ketersediaan fasilitas atau tempat penampungan sementara (Parta, 2012). Produksi sampah seringkali 
melampaui daya tampung TPS yang dimiliki oleh perumahan. Kondisi ini mengakibatkan timbulan sampah melebihi daya tampung TPS seperti terlihat pada Gambar 1 .

Di sisi lain, produksi sampah yang besar di BTN Banyuning Indah tidak terlepas dari kondisi ekonomi pemukim yang relatif berpendapatan menengah ke atas. Pendapatan dan waktu kerja yang relatif tinggi mengakibatkan pemukim lebih banyak memenuhi kebutuhan hidup dengan cara mengkonsumsi makanan dan minuman dalam kemasan, termasuk juga kebutuhan rumah tangga lainnya dalam kemasan kertas atau plastik. Kenyataan tersebut mengakibatkan produksi sampah perkotaan di BTN Banyuning Indah sangat besar dan merata hampir di seluruh Blok rumah. Dalam penelitian (Bargendra, 2012) menunjukkan bahwa komposisi sampah di Perumahan BTN Banyuning Indah bervariasi, dan jenis sampah yang mendominasi di perumahan tersebut adalah jenis sampah anorganik. Gambaran mengenai produksi sampah ditinjau dari timbulan dan komposisi sampah di BTN Banyuning Indah seperti terlihat pada Tabel 1.

Tabel 1. Produksi Sampah di BTN Banyuning Indah

\begin{tabular}{ccccc}
\hline \multirow{2}{*}{ No } & Blok & Timbulan Sampah & \multicolumn{2}{c}{ Komposisi Sampah (kg/orang/hari) } \\
\cline { 5 - 5 } & Rumah & (kg/orang/hari) & Organik & Anorganik \\
\hline 1 & $\mathrm{~A}$ & 3,0 & 1,0 & 2,0 \\
2 & $\mathrm{~B}$ & 3,2 & 0,5 & 2,7 \\
3 & $\mathrm{C}$ & 3,0 & 0,5 & 1,5 \\
4 & $\mathrm{D}$ & 2,8 & 1,0 & 1,8 \\
5 & $\mathrm{E}$ & 3,4 & 1,0 & 2,4 \\
6 & $\mathrm{~F}$ & 3,0 & 0,7 & 2,3 \\
7 & $\mathrm{G}$ & 4,0 & 1,2 & 2,8 \\
8 & $\mathrm{H}$ & 4,2 & 1,2 & 3,0 \\
9 & $\mathrm{I}$ & 4,7 & 1,0 & 3,1 \\
\hline & Total & 31,1 & 8,2 & 23,1
\end{tabular}

Sumber: Bargendra, 2012

Sampah yang dihasilkan pemukim di BTN Banyuning Indah tidak hanya dalam wujud limbah rumah tangga, tetapi juga barang bekas. Pemukim perumahan yang bersifat perkotaan senantiasa mengikuti arus perkembangan zaman. Hal ini mengakibatkan beberapa perlengkapan rumah tangga menjadi barang bekas. Kondisi ini mengakibatkan barang bekas yang bukan merupakan limbah rumah tangga, juga tertimbun di bagian ruang rumah tinggal yang secara umum terbatas. Dengan demikian, barang bekas yang membutuhkan ruang besar sebagai tempat penyimpanan.

Lingkungan perumahan di BTN Banyuning Indah memiliki keterbatasan ruang dalam mengakomodasi produksi dan berbagai tipikal limbah rumah tangga.
Kondisi ini serupa dengan rumah tempat tinggal di lingkungan perumahan yang memiliki keterbatasan ruang dalam mengakomodasi barang-barang bekas yang dimiliki pemukim. Keterbatasan ruang ini mengakibatkan pemukim melakukan beberapa strategi di dalam mengelola barang bekas yang dihasilkan tersebut. Berdasarkan hasil wawancara terbatas, ditemukan bahwa pemukim di perumahan BTN Banyuning Indah melakukan 3 strategi di dalam mengelola barang bekas yang dihasilkan. Adapun cara yang dilakukan sebagian besar atau $61 \%$ pemukim adalah dengan menjual kembali barang bekas kepada para pengepul, sebanyak 31\% dengan membuang barang bekas secara langsung dan sebanyak $8 \%$ dengan cara menyimpan barang bekas. 
Meskipun sebagian besar pemukim menjual kembali barang bekas kepada pengepul, akan tetapi terdapat permasalahan di dalam melakukan strategi tersebut. Permasalahan pertama yang dihadapi oleh para pemukim adalah kesulitan di dalam mengatur pertemuan dengan pengepul. Hal ini dikarenakan jadwal pengepul mengumpulkan barang bekas tidak teratur dan tidak sesuai dengan waktu yang dimiliki oleh para pemukim. Para pengepul sebagian besar hanya beroperasi pada hari minggu. Jam operasi pengepul tersebut berbenturan dengan waktu liburan pemukim yang dimanfaatkan untuk berekreasi keluarga atau pulang ke tempat asal, sehingga barang bekas yang akan dijual seringkali menumpuk dan merusak keindahan rumah seperti terlihat pada Gambar 2.

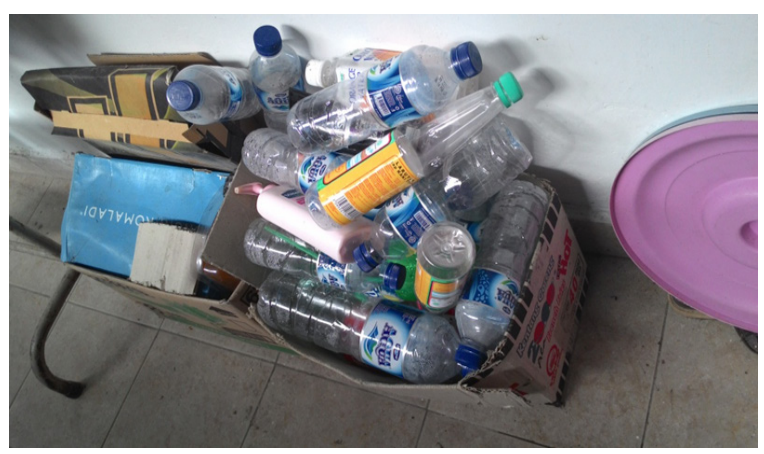

Gambar 2. Penumpukan Barang Bekas

Permasalahan kedua yang dialami oleh para pemukim adalah variasi harga beli kembali limbah rumah tangga dan barang bekas antara satu pengepul dengan pengepul lain sangat tinggi. Hal ini mengakibatkan pemukim menunggu pengepul tertentu yang dipandang memiliki harga beli kembali yang tinggi, sehingga pemukim kembali menghadapi permasalahan pertama. Permasalahan ketiga yang dialami adalah pengepul hanya menargetkan sampah atau barang bekas tertentu dan dalam jumlah tertentu untuk dapat ditransaksikan. Permasalahan keempat adalah perasaan tidak aman dan takut terhadap kemungkinan tindakan kejahatan terhadap kehadiran pengepul. Keempat permasalahan tersebut mengakibatkan limbah rumah tangga dan barang bekas yang dimiliki oleh pemukim semakin menumpuk. Penumpukan ini tidak hanya akan merusak keindahan rumah, tetapi juga akan berdampak pada gangguan kebersihan dan kesehatan rumah.

Permasalahan yang dihadapi dan dialami oleh pemukim BTN Banyuning Indah dalam mengelola limbah rumah tangga dan barang bekas merupakan potensi ekonomi baru. Potensi ekonomi baru yang dimaksud adalah di dalam aktivitas pengumpulan, pemilahan, penyaluran dan aktivitas pendaur-ulangan limbah rumah tangga dan barang bekas.

Ibu rumah tangga, khususnya yang bermukim di Blok I merupakan bagian pemukim BTN Banyuning Indah yang memiliki waktu lebih besar untuk dapat melakukan aktivitas yang lebih produktif. Berdasarkan hasil observasi awal terdapat $20 \mathrm{KK}$ dengan para istri yang hanya bekerja sebagai ibu rumah tangga. Dari $20 \mathrm{KK}$ tersebut menunjukkan bahwa sebagian besar dari ibu-ibu rumah tangga tersebut tergolong ke dalam usia produktif, yaitu rata-rata usia ibu rumah tangga adalah 45 tahun. Selain itu, ditinjau dari segi pendidikan, sebagian besar ibu rumah tangga tersebut berpendidikan terakhir SD, berpendidikan SMP $10 \%$, SMA $30 \%$ dan bahkan ada yang sampai jenjang Diploma III sebesar 10\%. Dari $20 \mathrm{KK}$ tersebut. Berdasarkan data tersebut, terlihat bahwa ibu-ibu rumah tangga di Blok I BTN Banyuning Indah memiliki peluang usaha yang sangat besar.

Secara makro peluang usaha yang dimiliki adalah aktivitas produksi dan manajemen. Aktivitas produksi meliputi yaitu pendaur-ulangan limbah dan barang bekas menjadi barang yang bermanfaat dan bernilai jual sedangkan aktivitas manajemen meliputi pengumpulan, pemilahan hingga pemasaran.

Aktivitas pengelolaan ini secara langsung dapat membantu kemandirian keluarga ibuibu rumah tangga, khususnya pemukim di Blok I BTN Banyuning Indah dalam mencapai kesejahteraan ekonomi keluarga. Di samping itu, aktivitas ini secara tidak langsung akan mempererat hubungan sosial diantara pemukim, sehingga akan ikut menjaga kerukunan 
warga dan keamanan lingkungan. Dan dalam jangka panjang, aktivitas pengelolaan ini akan berkontribusi besar terhadap kebersihan, keindahan dan kesehatan lingkungan di BTN Banyuning Indah.

Meskipun sudah mengetahui secara umum bahwa aktivitas pengumpulan limbah rumah tangga dan barang bekas di lingkungan perumahan, yang secara ironis dilakukan oleh pengepul yang berasal dari luar BTN Banyuning Indah sangat menjanjikan, tetapi pemukim BTN Banyuning Indah, khususnya ibu-ibu rumah tangga enggan mengambil peluang usaha ini. Hal ini dikarenakan tidak memiliki informasi tentang mekanisme pemanfaatan dan pengelolaan limbah rumah tangga dan barang bekas. Di sisi lain, belum ada instansi yang secara kontinu dan holistik di dalam memberikan pembinaan, pelatihan dan bimbingan teknis dalam pengelolaan limbah rumah tangga dan barang bekas.

Implikasi dari permasalahan ini akan mengurangi kesadaran ekonomi yang dimiliki pemukim BTN Banyuning Indah, dan lebih jauh juga akan mengurangi kesadaran lingkungan. Kesadaran ekonomi yang rendah akan mengakibatkan sikap acuh pemukim terhadap berbagai potensi yang ada, dan akan memicu sikap abai terhadap peluang usaha yang dapat dikelola dan diberdayakan. Kesadaran lingkungan yang terbentuk sebagai pola pikir pemukim, khususnya ibu-ibu rumah tangga akan menjadi sempit dengan memandang bahwa permasalahan limbah rumah tangga dan barang bekas yang dihadapi pemukim lain adalah permasalahan rumah tangga pemukim itu sendiri, sementara penciptaan lingkungan yang bersih hanya sebatas lingkungan rumah tempat tinggal mereka.

Strategi program kemitraan dalam wujud pembinaan dan pemberian pengetahuan dalam secara kontinu dan holistik diperlukan untuk membentuk kelompok masyarakat, yang dalam hal ini adalah pemukim BTN Banyuning Indah agar mampu menjadi agenagen perubahan dan pembaharuan sebagai masyarakat pengelola sampah, khususnya barang bekas dan limbah rumah tangga yang diproduksi oleh pemukim di kompleks perumahan BTN Banyuning Indah.

\section{METODE PELAKSANAAN}

Pelaksanaan dalam program Kemitraan ini dirancang dengan sistem kerja yang sistematis meliputi: (1) kegiatan pembinaan, untuk pembentukan pola pikir dan perilaku yang berorientasi keuntungan bersama, dari sisi ekologis dan ekonomi dan (2) kegiatan pelatihan, untuk pengembangan pengetahuan dan kemampuan dalam pemanfaatan sampah. Adapun alur kerja langkah-langkah pelaksanaan program kemitraan ini seperti terlihat pada Tabel 2.

Tabel 2. Alur Kerja Langkah-Langkah Pelaksanaan Program Kemitraan

\begin{tabular}{lcc}
\hline No & $\begin{array}{c}\text { Langkah Pelaksanaan } \\
\text { Program }\end{array}$ & Kegiatan \\
\hline
\end{tabular}

1 Pembinaan:

(1) permasalahan sampah Membangun pemahaman mitra terkait dampak negatif yang ditimbulkan akibat permasalahan sampah di lingkungan kompleks perumahan.

(2) perilaku sadar ekologis Membangun pola pikir mitra terkait sikap-sikap sadar lingkungan yang perlu ditumbuhkan dari lingkungan keluarga, khususnya sikap sadar akan kesehatan dan kebersihan rumah.

(3) perilaku sadar ekonomis Membangun pola pikir mitra terkait sikap-sikap sadar ekonomi yang perlu dikembangkan dalam menangkap peluang usaha dari keberadaan sampah di lingkungan perumahan.

2 Pelatihan:

(1) pemanfaatan sampah Melatih kemampuan mitra untuk mengidentifikasi jenis sampah yang dapat dimanfaatkan untuk dikelola 
Program kemitraan ini merupakan program yang bersifat holistik dalam rangka peningkatan kesadaran pemukim perumahan, khususnya ibu-ibu rumah tangga di BTN Banyuning Indah mengenai teknik pengelolaan sampah sebagai peluang usaha yang prospektif dengan langkah pembinaan, pelatihan dan pendampingan. Dalam upaya pencapaian program ini, maka pendekatan yang dipandang relevan untuk digunakan adalah pendekatan kemadirian (the self-reliance approaches). Pendekatan kemadirian ini berkesesuaian dengan kondisi mitra progam agar terlepas dari ketergantungan terhadap pihak lain dalam mengelola sumberdaya (Christiawan, Citra, \& Wahyuni, 2016). Pendekatan kemandirian ini menekankan pada hubungan timbal-balik dan saling menguntungkan dalam pengelolaan serta lebih mengandalkan kemampuan dan sumberdaya mitra sendiri untuk pembangunan (Roesmidi \& Risyanti, 2006).

Mitra dalam pelaksanaan program Kemitraan ini adalah ibu-ibu rumah tangga Blok I di BTN Banyuning Indah yang belum produktif secara ekonomi, tetapi berhasrat kuat menjadi wirausahawan. Hasrat yang kuat ini didukung dengan sampah perumahan yang relatif besar. Berdasarkan pada lingkup permasalahan yang dihadapi mitra, maka tolak ukur transfer dari program Kemitraan adalah dengan menyasar 2 kelompok mitra, yang masing-masing terdiri dari 3 ibu rumah tangga. Perwakilan ibu-ibu rumah tangga tersebut selanjutnya dibina, dilatih dan didampingi dalam hal teknik pengelolaan sampah perumahan.

\section{HASIL DAN PEMBAHASAN}

Proses pelaksanaan program kemitraan dilaksanakan dengan kegiatan pembinaan yang memberikan penyuluhan tentang perilaku sadar lingkungan dan ekonomi, serta kegiatan pelatihan untuk mengidentifikasi pemanfaatan barang bekas dan limbang rumah tangga yang berorientasi ekologis dan ekonomis.

\section{Membangun Perilaku Sadar Ekologis dan Ekonomis}

Perilaku manusia terhadap lingkungan dapat dipilah menjadi 2, yaitu perilaku ekosentrik dan antroposentrik. Individu yang bersikap ekosentrik memandang bahwa perlindung terhadap lingkungan alam dilakukan untuk kepentingan lingkungan itu sendiri. Sikap permasalahan lingkungan karena merasa bahwa alam patut mendapat perlindungan bukan karena pertimbanganpertimbangan ekonomis, tetapi lebih ke pertimbangan spiritual (Katz \& Oescsli, 1993) atau pertimbangan moral (Seligman dalam Thompson \& Barton, 1994).

Antroposentrik adalah kecenderungan untuk memandang alam sebagai suatu sumber yang bisa dimanfaatkan untuk kepentingan manusia. Konsep ini menggunakan kesejahteraan manusia sebagai alasan utama dari setiap tindakannya (Shrivasta, 1995). Individu dengan kecenderungan antroposentrik berpendapat bahwa lingkungan perlu dilindungi karena nilai yang terkandung di dalam lingkungan sangat bermanfaat bagi kelangsungan hidup manusia. Perhatian orang dengan sikap antroposentris terhadap lingkungan alam lebih karena kepentingan dirinya (Thompson \& Barton, 1994).

Pembentukan perilaku sangat dipengaruhi oleh sistem nilai yang dianut seseorang (Widiyanta, 2005). Dengan kata lain, perilaku mitra dalam memandang makna sampah sangat dipengaruhi oleh nilai, yang dalam kajian ini dibagi menjadi nilai ekologis dan nilai ekonomis.

Nilai ekologis adalah memandang bahwa pemanfaatan sampah memiliki peranan dalam mempertahankan keberlanjutan ekosistem, dan menjaga daya dukung lingkungan. Sedangkan nilai ekonomis berarti memandang bahwa limbah yang melalui proses lebih lanjut atau diolah dapat memberikan nilai tambah. Perilaku sadar ekologis dan ekonomis mitra dapat diukur dengan indikator frekuensi partisipasi mereka dalam aktivitas-aktivitas yang berkenaan dengan keuntungan ekologis dan ekonomis. 
Dalam upaya menganalisis perilaku mitra secara praktis, maka dipilih perilaku sederhana yang dilakukan oleh mitra dalam kehidupan sehari-hari. Hal ini juga memudahkan mitra untuk memahami maksud dari setiap indikator. Perilaku ekologis mitra seperti terlihat pada Tabel 3.

Tabel 3. Partisipasi Mitra dalam Perilaku Ekologis Aktual

\begin{tabular}{|c|c|c|c|c|c|c|c|}
\hline \multirow[t]{2}{*}{ No } & \multirow[t]{2}{*}{ Perilaku Sadar Lingkungan } & \multicolumn{2}{|c|}{ Selalu } & \multicolumn{2}{|c|}{$\begin{array}{l}\text { Tidak } \\
\text { Selalu }\end{array}$} & \multicolumn{2}{|c|}{$\begin{array}{l}\text { Tidak } \\
\text { Pernah }\end{array}$} \\
\hline & & $\mathbf{N}$ & $\%$ & $\mathbf{N}$ & $\%$ & $\mathbf{N}$ & $\%$ \\
\hline 1 & Membawa kantong plastik setiap pergi berbelanja & 2 & 33,33 & 2 & 33,33 & 2 & 33,33 \\
\hline 2 & Membawa botol air setiap bepergian & 2 & 33,33 & 1 & 16,67 & 3 & 50,00 \\
\hline 3 & $\begin{array}{l}\text { Mendorong keluarga dan tetangga untuk tidak membuang } \\
\text { sampah sembarangan }\end{array}$ & 5 & 83,33 & 1 & 16,67 & 0 & 0,00 \\
\hline 4 & $\begin{array}{l}\text { Memilah tempat sampah antara sampah organik dan } \\
\text { anorganik }\end{array}$ & 1 & 16,67 & 1 & 16,67 & 4 & 66,67 \\
\hline
\end{tabular}

Berdasarkan Tabel 3 terlihat bahwa $83,33 \%$ mitra telah mendorong keluarga dan tetangga sekitar tempat tinggal mereka untuk menjaga kebersihan dan kesehatan lingkungan. Akan tetapi, sebagian besar mitra masih menggabungkan tempat sampah untuk sampah organik dan anorganik.

Hal ini sejalan juga dengan mitra yang sebagian besar tidak membawa botol air di setiap bepergian, sehingga selalu membeli air dalam botol kemasan untuk konsumsi di luar rumah. Dalam hal mempersiapkan kantong plastik sebagai tempat barang belanjaan, persentase mitra seimbang antara yang selalu membawa, tidak selalu membawa dan tidak pernah membawa. Secara umum perilaku mitra menunjukkan nilai positif terhadap nilai ekologis, tetapi masih terdapat sebagian kecil perilaku ekologis mitra yang bersifat negatif, terutama dalam hal meminimalisir penggunaan kantong dan minuman dalam kemasan plastik.

Dalam upaya menganalisis perilaku ekonomi mitra, maka dipilih perilaku sederhana yang dilakukan oleh mitra dalam memperlakukan produk yang bersumber dari plastik. Adapun perilaku ekonomis mitra seperti terlihat pada Tabel 4.

Tabel 4. Partisipasi Mitra dalam Perilaku Ekonomis Aktual

\begin{tabular}{|c|c|c|c|c|c|c|c|}
\hline \multirow[t]{2}{*}{ No } & \multirow[t]{2}{*}{ Perilaku Sadar Ekonomi } & \multicolumn{2}{|c|}{ Selalu } & \multicolumn{2}{|c|}{$\begin{array}{l}\text { Tidak } \\
\text { Selalu }\end{array}$} & \multicolumn{2}{|c|}{$\begin{array}{c}\text { Tidak } \\
\text { Pernah }\end{array}$} \\
\hline & & $\mathbf{N}$ & $\%$ & $\mathbf{N}$ & $\%$ & $\mathbf{N}$ & $\%$ \\
\hline 1 & Membeli produk yang dapat diisi ulang & 5 & 83,33 & 1 & 16,67 & 0 & 0,00 \\
\hline 2 & Membayar kantong plastik untuk tempat barang belanjaan & 2 & 33,33 & 2 & 33,33 & 2 & 33,33 \\
\hline 3 & Menjual botol plastik dan barang bekas ke pengepul & 3 & 50,00 & 2 & 33,33 & 1 & 16,67 \\
\hline 4 & Menggunakan kembali botol plastik untuk kegunaan lain & 4 & 66,67 & 1 & 16,67 & 1 & 16,67 \\
\hline
\end{tabular}

Berdasarkan Tabel 4 terlihat bahwa $83,33 \%$ mitra telah membeli produk-produk kebutuhan hidup sehari-hari yang bersifat dapat diisi ulang. Produk isi ulang akan dapat memanfaatkan kemasan awal kembali sebagai tempat produk. Produk yang bersifat isi ulang ini terutama adalah produk-produk kebersihan, dan beberapa produk pelengkap masakan. Sebagian besar mitra juga menggunakan kembali botol-botol plastik untuk berbagai kegunaan, terutama sebagai tempat detergen, tempat alat tulis dan sebagian digunakan untuk media atau pot tanaman. Botol plastik yang tidak dapat digunakan kembali oleh sebagian mitra dijual kepada pengepul sampah. Secara umum perilaku 
mitra menunjukkan nilai positif terhadap nilai ekonomis. Kenyataan ini terlihat dari perilaku mitra yang memanfaatkan kembali barang bekas atau limbah rumah tangga, meskipun untuk pemanfaatan yang sederhana atau tidak mengubah bentuk dari produk yang sudah tidak terpakai tersebut.

Pembinaan dilaksanakan untuk memberika pemahaman baru tentang sampah dari sisi ekologis dan ekonomis. Dari sisi ekologis, sampah yang terbuat dari bahan plastik akan memberikan dampak negatif yang besar terhadap lingkungan, terutama pencemaran air dan tanah. Sampah plastik yang mayoritas bersumber dari botol minuman adalah salah satu sampah yang sangat sulit diurai atau baru dapat diurai setelah 250 sampai 450 tahun. Sedangkan dari sisi ekonomi, sampai dapat diolah menjadi berbagai produk yang lebih bermanfaatn dan bernilai jual. Setelah mengikuti kegiatan pembinaan ini, mitra kembali diberikan instrumen untuk memantau perubahan pola pikir dan perilaku di dalam memanfaatkan sampah.

Secara umum terdapat perbedaan pemahaman dan pola pikir mitra sebelum dan sesudah mengikuti pembinaan. Perbedaan tersebut seperti terlihat pada Tabel 5.

Tabel 5. Kondisi Sebelum dan Sesudah Pelaksanaan Pembinaan

\begin{tabular}{clll}
\hline No & \multicolumn{1}{c}{ Uraian } & Pola Pikir Sebelum Pembinaan & Pola Pikir Setelah Pembinaan \\
\hline 1 & $\begin{array}{l}\text { Gambaran umum } \\
\text { tentang sampah }\end{array}$ & $\begin{array}{l}\text { Masih memandang sampah } \\
\text { sebagai benda yang tidak bernilai }\end{array}$ & $\begin{array}{l}\text { Mengetahui peluang dan potensi } \\
\text { sampah perumahan }\end{array}$ \\
& $\begin{array}{l}\text { Bentuk pengelolaan } \\
\text { sampah }\end{array}$ & $\begin{array}{l}\text { Sampah hanya dapat digunakan } \\
\text { kembali secara sementara }\end{array}$ & $\begin{array}{l}\text { Sampah dapat diolah atau dibuah } \\
\text { dengan menjadi produk yang } \\
\text { bernilai }\end{array}$ \\
3 & $\begin{array}{l}\text { Kemampuan } \\
\text { mengidentifikasi } \\
\text { pemanfaatan sampah }\end{array}$ & $\begin{array}{l}\text { Belum mengetahui bahan, alat } \\
\text { dan cara memanfaatkan sampah }\end{array}$ & $\begin{array}{l}\text { Mengetahui bahan, alat dan cara } \\
\text { memanfaatkan sampah secara } \\
\text { kreatif }\end{array}$ \\
& $\begin{array}{l}\text { Gambaran umum } \\
\text { tentang berwirausaha }\end{array}$ & $\begin{array}{l}\text { Belum memiliki gambaran } \\
\text { berwirausaha di perumahan }\end{array}$ & $\begin{array}{l}\text { Mengetahui peluang, potensi } \\
\text { dan hambatan berwirausaha di } \\
\text { perumahan }\end{array}$ \\
5 & Motivasi berwirausaha & Kurang semangat berwirausaha \\
& & & $\begin{array}{l}\text { Antusias dan semangat } \\
\text { mengikuti diskusi tentang } \\
\text { berwirausaha }\end{array}$ \\
\hline
\end{tabular}

Berdasarkan Tabel 5 terlihat perbedaan kondisi sebelum dan sesudah pelatihan. Berdasarkan hasil pengamatan, terdapat perubahan baik dari aspek pengetahuan, sikap dan kemampuan. Melalui diskusi, mitra mengetahui potensi, kelemahan, peluang, dan langkah yang dapat dilakukan dalam memanfaatkan sampah perumahan. Selain itu, mitra termotivasi untuk berwirausaha dengan memanfaatkan potensi sampah perumahan di BTN Banyuning Indah. Terlihat peningkatan minat mitra terhadap usaha pengelolaan sampah. Ichsan, Wibowo, \& Sidiq (2015) dalam kegiatan penyuluhan yang berbeda menyatakan bahwa peningkatan pengetahuan akan dapat mengubah sikap dan tindakan mitra menjadi lebih baik. Kegiatan pembinaan juga dinyatakan sebagai kegiatan pemberdayaan tahap pertama dalam upaya meningkatkan pengetahuan mitra sebagai kader pembangunan (Maryatun \& Indarwati, 2017). Peningkatan motivasi ini sejalan dengan peningkatan kemampuan komunikasi mitra. Kemampuan komunikasi yang baik akan membantu pelaksanaan usaha dari sisi promosi (Testiana, Mulyadi, \& Faturrahman, 2016).

\section{Mereorientasi Pemanfaatan Sampah}

Kegiatan kedua adalah pelatihan. Kegiatan pelatihan menekankan pada pengetahuan tentang pemanfaatan sampah. 
Pelatihan ini juga memberi keterampilan kepada mitra dalam mengidentifikasi pemanfaatan sampah perumahan, yang bersumber dari barang bekas dan limbah rumah tangga. Pengetahuan yang dimiliki mitra akan memperkuat motivasi mereka dalam berwirausaha. Mitra yang sudah termotivasi akan secara aktif menuangkan ide dan gagasan ke dalam berbagai bentuk kreativitas (Rahmawati, Santosa, \& Muhroji, 2015).

Bentuk ide yang dituangkan mitra terlihat pada identifikasi yang dirancang. Rancangan identifikasi mitra dalam mereorientasi pemanfaatan sampah seperti terlihat pada Tabel 6 .

Tabel 6. Identifikasi Pemanfaatan Sampah Berorientasi Ekologis dan Ekonomis

\begin{tabular}{|c|c|c|c|}
\hline No & Jenis Produk & Bentuk Produk & Sumber/Bahan \\
\hline \multirow[t]{3}{*}{1} & Produk Seni & 1.1 Jam Dinding & $\begin{array}{l}\text { - Tutup Botol Plastik Minuman } \\
\text { - Sedotan } \\
\text { - Mesin Jam }\end{array}$ \\
\hline & & 1.2 Tempat Charger Hp & $\begin{array}{l}\text { - Botol Plastik Lotion } \\
\text { - Botol Plastik Kosmetik }\end{array}$ \\
\hline & & 1.3 Gantungan Kunci & $\begin{array}{l}\text { - Tutup Botol Plastik Minuman } \\
\text { - Rantai Gantungan Kunci }\end{array}$ \\
\hline \multirow[t]{3}{*}{2} & $\begin{array}{l}\text { Produk Perabotan } \\
\text { Rumah Tangga }\end{array}$ & 2.1 Sapu & $\begin{array}{l}\text { - Botol Plastik Minuman 1,5 Lt } \\
\text { - Pipa/tongkat kayu }\end{array}$ \\
\hline & & 2.2 Bag Traveler & $\begin{array}{l}\text { - Botol Plastik Minuman Sedang-Kecil } 300 \mathrm{ml} \\
\text { - Zipper/Resleting }\end{array}$ \\
\hline & & 2.3 Tempat Sikat Gigi & - Botol Plastik Minuman Sedang-Kecil $300 \mathrm{ml}$ \\
\hline
\end{tabular}

Mitra yang terbagi ke dalam 2 kelompok mengidentifikasi pemanfaatan sampah yang berorientasi ekologis dan ekonomis. Kedua mitra memiliki kedudukan yang sama sebagai wirausaha utama yang akan mengelola sampah perumahan. Perbedaan antara kedua kelompok terletak pada fokus pengelolaan. Mitra 1 akan memfokuskan pada pengelolaan sampah menjadi produk seni, sedangkan Mitra 2 akan berfokus pada pengelolaan sampah menjadi produk perabotan rumah tangga.

Kedudukan mitra ini berbeda dengan kegiatan pengembangan usaha yang dilaksanakan oleh (Supriyanto, Santosa, \& Basukianto, 2016) yang membagi mitra menjadi 2 kelompok dengan kedudukan yang berbeda. Salah satu kelompok Mitra 1 menjadi induk atau inti usaha, sedangkan kelompok mitra 2 berperan sebagai plasma. Mitra 1 setelah adanya pelatihan dan pendampingan kemitraan dapat memberikan bimbingan dan pinjaman alat kepada Mitra 2 , serta membantu pemasaran produk kepada Mitra 2. Selain itu, dalam kegiatan ini, mitra
1 juga memberikan supplier bahan-bahan baku usaha, yang selanjutnya dapat dibuat produknya oleh mitra 2.

\section{SIMPULAN DAN SARAN}

\section{Simpulan}

1. Kegiatan pembinaan ini telah berhasil memberi wawasan tentang potensi dan peluang usaha pengelolaan sampah perumahan serta motivasi kepada mitra untuk berwirausaha di perumahan hBTN Banyuning Indah. Pelatihan ini juga berhasil memberi kemampuan mitra untuk mengidentifikasi pemanfaatan sampah berorientasi ekologis dan ekonomi dalam bentuk produk seni dan produk perabotan rumah tangga.

2. Tanggapan mitra terhadap pelaksanaan kegiatan pembinaan dan pelatihan ini sangat baik. Hal ini dapat dilihat dari kehadiran peserta mencapai $100 \%$ dari target, dan selama kegiatan berlangsung mitra sangat antusias dan proaktif mengikuti kegiatan ini. 


\section{Saran}

Program kemitraan di Perumahan BTN Banyuning Indah Kota Singaraja ini mendapat sambutan positif dari pemukim perumahan. Pengetahuan pemanfaatan sampah ini diharapkan akan dapat direalisasikan ke dalam bentuk purwarupa produk, dan dikembangkan ke dalam berbagai variasi bentuk maupun kegunaan produk.

Selain itu, melihat potensi sampah perumahan ini, mitra diharapkan dapat memanfaatkan pengetahuan dan kemampuan yang diperoleh sebagai peluang usaha berkelanjutan. Melihat sambutan dan motivasi mitra yang positif, perlu adanya tindak lanjut dari dinas terkait untuk ikut serta merealisasikan dan mengembangkan usaha pengelolaan sampah di perumahan ini. Pelatihan terkait pengelolaan sampah dan pengembangan usaha pun perlu diadakan, meliputi proses pembuatan produk, komunikasi pemasaran, dan permohonan kerjasama atau bantuan usaha sehingga pelatihan semacam ini dapat berjalan secara berkelanjutan.

\section{DAFTAR PUSTAKA}

Bargendra, Y. G. (2012). Pemetaan Persebaran Titik Penimbunan Sampah Ilegal Di Kota Singaraja. Universitas Pendidikan Ganesha, Singaraja.

Christiawan, P. I., Citra, I. P. A., \& Wahyuni, M. A. (2016). Penataan permukiman kumuh masyarakat pesisir di desa sangsit. Jurnal Widya Laksana, 5(2), 52-59.

Damanhuri, E., \& Padmi, T. (2010). Pengelolaan Sampah. Bandung: ITB.

Environmental Protection Agency. (2011). Fact and Figures Municipal Solid Waste In The United States.

Ichsan, B., Wibowo, B. H., \& Sidiq, M. N. (2015). Penyuluhan Pentingnya Sayuran BagianakAnak Di Tkaisyiyah Kwadungan, Trowangsan, Malangjiwan, Colomadu, Karanganyar, Jawatengah. Warta, 18(1), 29-35.

Katz, E., \& Oescsli, L. (1993). Moving Beyond Antropocentrism: Environmental Ethics, Development, And The Amazon Environmental Ethic. Spring, 15, 49-59.

Maryatun, \& Indarwati. (2017). Pemberdayaan Kader Posyandu Dalam Pengelolaan Posyandu Lansia Aktif Di Desa Jetis Sukoharjo. Warta, 20(1), 55-60.

Parta, M. T. D. (2012). Evaluasi Ketersediaan Prasarana Sarana Dan Utilitas Umum Pada Kompleks Perumahan Di Kecamatan Buleleng Kabupaten Buleleng. Universitas Pendidikan Ganesha, Singaraja.

Rahmawati, L. E., Santosa, J., \& Muhroji.(2015). IbMPengembangan Keprofesian Berkelanjutan (Pkb) Guru-Guru Wilayah Ngawen Dan Klaten Utara Berbasis Kurikulum 2013. Warta, 18(2), 135-144. https://doi.org/10.1017/CBO9781107415324.004

Roesmidi, H., \& Risyanti, R. (2006). Pemberdayaan Masyarakat (Cetakan 2). Sumedang: Penerbit Al-qaprint Jatinangor.

Shrivasta, P. (1995). Ecocentric Management For A Risk Society. Academy of Management Review, 20(1), 118-137.

Supriyanto, A., Santosa, A. B., \& Basukianto. (2016). Pengembangan usaha berbahan kain limbah dan velboa di kota semarang. Abdimas, 20(1), 1-10. 
Testiana, D., Mulyadi, D., \& Faturrahman, A. (2016). Peningkatan Kemampuan Berbahasa Inggris Dan Manajemen Pemasaran Melalui Web Bagi Pemilik Homestay Desa Wisata Kandri Semarang. Abdimas, 20(1), 61-65.

Thompson, S. ., \& Barton, M. . (1994). Ecocentric And Anthroposentric Attitudes Toward The Environment. Journal of Environment Psychology, 14, 149-157.

Widiyanta, A. (2005). Sikap Terhadap Lingkungan Dan Religiusitas. Psikologia, I(2), 86-95. 